\title{
Determinants of Innovative Activity in Canadian Manufacturing Firms: The Role of Intellectual Property Rights
}

\author{
by \\ John Baldwin* \\ Petr Hanel** \\ David Sabourin***
}

No. 122

11F0019MPE No. 122

ISSN: 1200-5223

ISBN: 0-660-17543-6

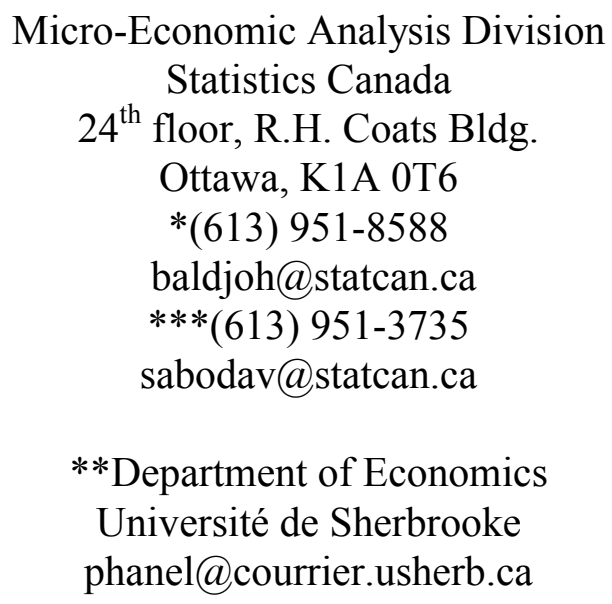

March 7, 2000

A version of this paper will be published as "The Determinants of Innovation in Canadian Manufacturing Firms" in Alfred Kleinknecht and Pierre Mohnen (eds.): Innovation and firm performance. Macmillan: London. Forthcoming.

The authors' names are listed alphabetically.

This paper represents the views of the authors and does not necessarily reflect the opinions of Statistics Canada. 


\section{Table of Contents}

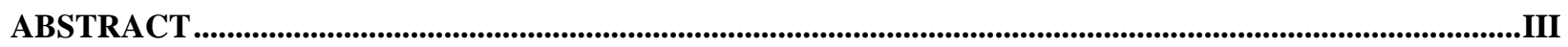

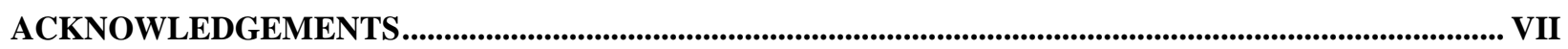

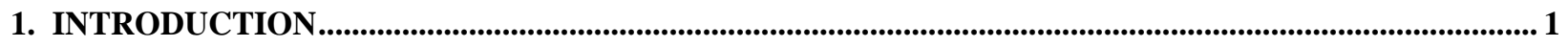

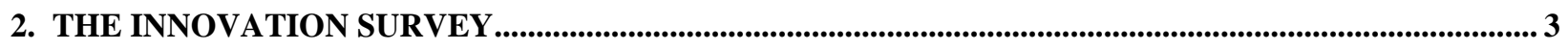

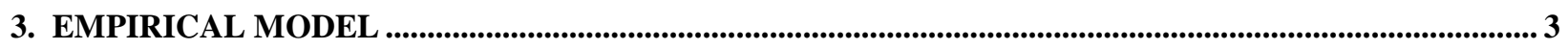

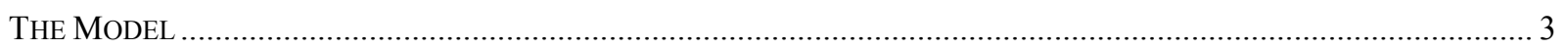

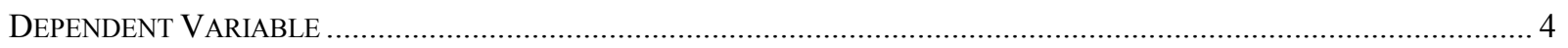

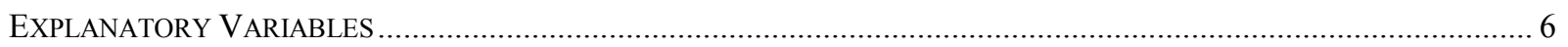

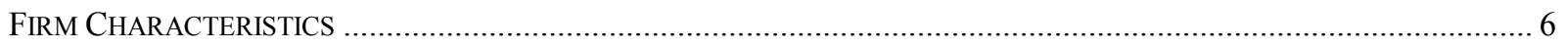

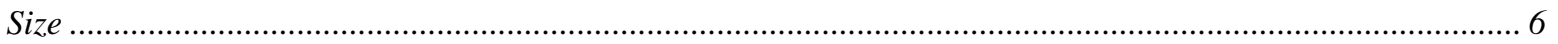

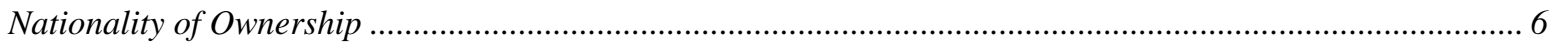

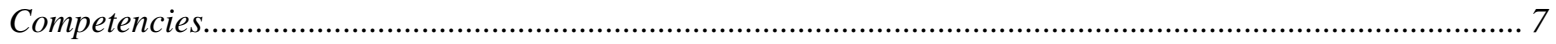

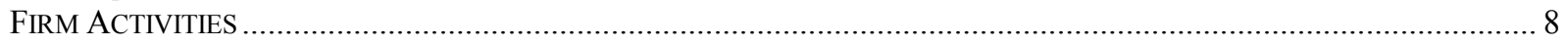

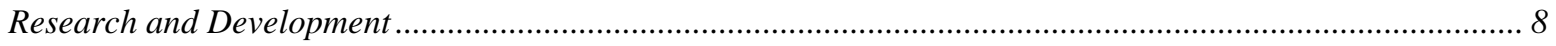

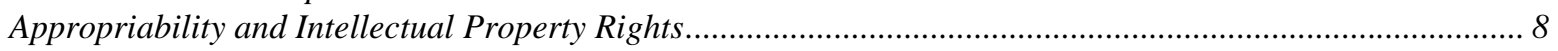

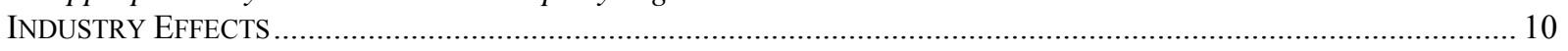

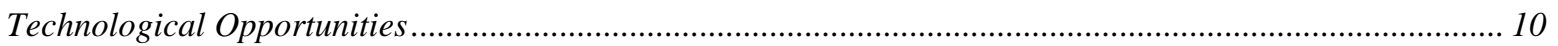

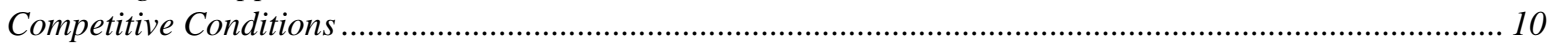

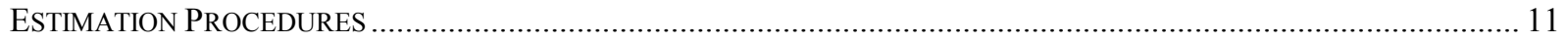

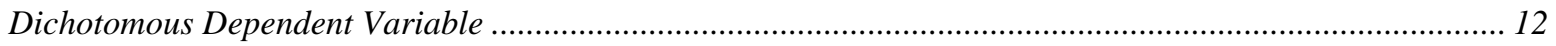

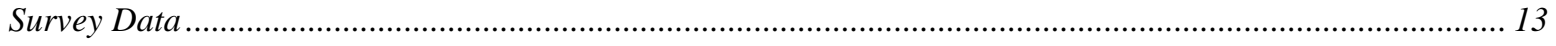

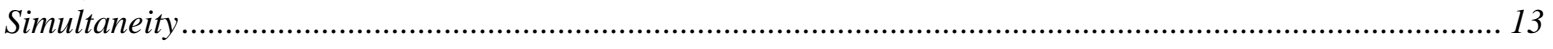

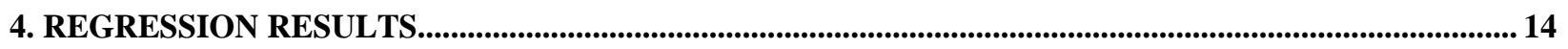

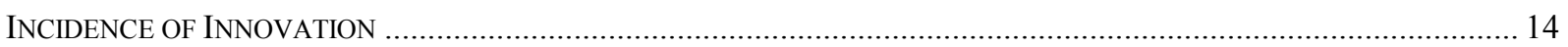

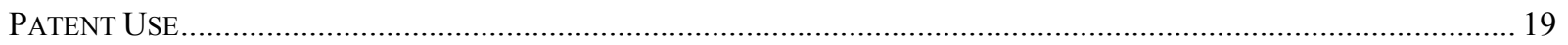

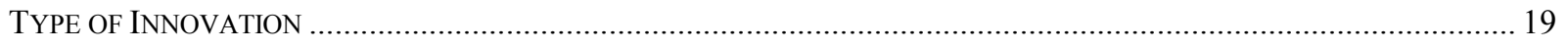

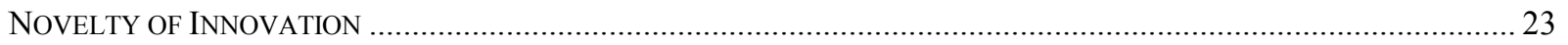

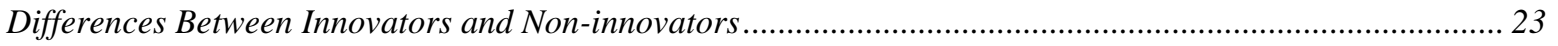

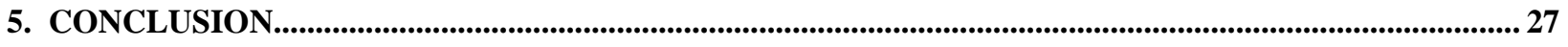

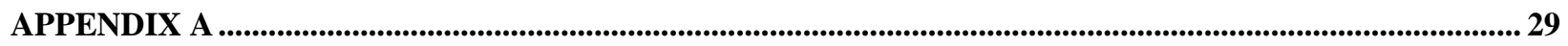

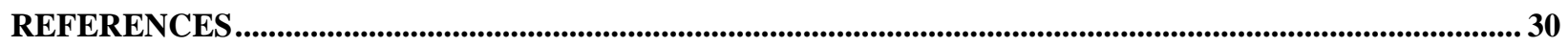

\begin{tabular}{lll}
\hline Analytical Studies Branch - Research Paper Series & - iii - & Statistics Canada No. 11F0019MPE No. 122
\end{tabular} 


\section{Abstract}

This paper examines how several factors contribute to innovative activity in the Canadian manufacturing sector. First, it investigates the extent to which intellectual property right protection stimulates innovation. Second, it examines the contribution that R\&D makes to innovation. Third, it considers the importance of various competencies in the areas of marketing, human resources, technology and production to the innovation process. Fourth, it examines the extent to which a larger firm size and less competition serve to stimulate innovation-the socalled Schumpeterian hypothesis. Fifth, the effect of the nationality of a firm on innovation is also investigated. Finally, the paper examines the effect of an industry's environment on a firm's ability to innovate.

Several findings are of note. First, the relationship between innovation and patent use is found to be much stronger going from innovation to patent use than from patent use to innovation. Firms that innovate take out patents; but firms and industries that make more intensive use of patents do not tend to produce more innovations. Second, while R\&D is important, developing capabilities in other areas, such as technological competency and marketing, is also important. Third, size effects are significant. The largest firms tend to be more innovative. As for competition, intermediate levels of competition are the most conducive to innovation. Fourth, foreign-controlled firms are not significantly more likely to innovate than domestic-controlled firms once differences in competencies have been taken into account. Fifth, the scientific infrastructure provided by university research is a significant determinant of innovation.

Keywords: innovation, intellectual property rights, research and development, scientific infrastructure, Schumpeterian hypothesis 


\section{Acknowledgements}

We would like to thank Bronwyn Hall, Alfred Kleinknecht, Pierre Mohnen and other members of the European Innovation Network for their comments. 


\section{Introduction}

The topic of innovation has garnered the interest of a select group of economists from Schumpeter (1942) to Nelson and Winter (1982), who have stressed that it is the key to economic growth. However, until the advent of panel datasets, there was little empirical evidence to link the innovative stance of firms and their performance. Recent work that links dynamic panel datasets on the performance of firms and special surveys on the strategies that are being pursued by firms have demonstrated the importance of innovation to growth. Baldwin, Chandler et al. (1994) demonstrate that in small and medium-sized Canadian firms, a measure of success that is based on growth, profitability and productivity is strongly related to the emphasis that firms place on innovation. Baldwin and Johnson (1999) use a sample of entrants to show that growth in new firms depends upon whether the firm innovates. Crépon, Duguet and Mairesse (1998) find that innovation in French firms increases productivity.

While we have evidence, therefore, on the connection between success and innovation, there is less evidence on the factors that condition whether a firm adopts an innovation policy. Not all firms innovate despite the benefits of doing so. Research has, therefore, been aimed at understanding the conditions that are associated with being innovative. ${ }^{1}$ A number of questions have been posed in this literature - the extent to which the intellectual property regime stimulates innovation; whether the exclusive emphasis that is given to R\&D ignores the importance of other inputs; the effect of firm size and market structure on the intensity of innovation; and the extent to which multinational firms are more innovative. In this paper, we use data from the 1993 Canadian Survey of Innovation and Advanced Technology to study the differences between firms that innovate and those that do not innovate and to address the following issues.

The first is the extent to which the intellectual property regime stimulates innovation. Patents are seen to be a key form of protection for innovation, but Mansfield (1986) and Levin et al. (1987), using data from firm-based surveys, have presented empirical work that suggests that patents may not be that important in many sectors. More recently, Cohen, Nelson and Walsh (1996) and Baldwin (1997a) present additional survey evidence for the United States and Canada, respectively, that other ways of protecting intellectual property, such as being first in the market, using trade secrets, and developing complex designs, are more effective than patents.

The second issue is whether the existence of an R\&D unit is essential to innovation. While it is traditional to emphasize the importance of R\&D facilities to the innovation process, Mowery and Rosenberg (1989) have stressed that a good deal of innovation comes out of engineering departments and production facilities.

\footnotetext{
${ }^{1}$ For related studies covering France, Germany, Italy, Holland, and Switzerland, see Crépon, Duguet and Kabla (1996), Felder et al. (1996), Sterlacchini (1994), Brouwer and Kleinknecht (1996), Arvanitis and Hollenstein (1994, 1996).
} 
Third, we investigate whether there are other competencies besides the development of a research and development unit that are closely linked to innovation. Successful innovators not only have to develop new products; they also have to develop the technology to produce them; they have to put together successful marketing programs; they have to master production logistics. Baldwin and Johnson (1995) demonstrate that innovators and non-innovators in small and medium-sized firms differ with regards to the emphasis that they place on a wide-range of competenciesranging from marketing to human resources.

The fourth issue is the extent to which a larger average firm size and less competition stimulate innovation. Often described as the Schumpeterian hypothesis, it is sometimes claimed that innovation is fostered by a climate where firms are large or in industries where there is less competition. While there is mixed evidence that either matter (Scherer, 1992), the issue continues to receive attention (Cohen and Klepper, 1996a, 1996b).

The fifth question deals with the effect of the nationality of a firm on its innovative tendencies. Both Dunning (1993) and Caves (1982) have stressed the special role of the multinational firm in transferring special innovation skills from one nation state to another. The role of multinationals in Canada is particularly important since they control over half of the manufacturing sector. McFetridge (1993) stresses the importance of linkages from Canada into the world innovation system that are accomplished through multinationals.

Finally, we examine the importance of the scientific infrastructure that is stressed by Tassey (1991). The environment facing each industry is seen to condition a firm's ability to innovate. On the one hand, the availability and quality of education, private and public technical services such as test laboratories, and standardization institutes, as well as research institutes favours innovation. On the other hand, firms also need educational infrastructure to take account of new knowledge. The state of a country's higher educational facilities will affect a firm's ability to digest new information.

Throughout the exercise, we examine these issues for different types of innovations. Innovation surveys allow us to examine the determinants of the output of the innovative process. In that respect, they are superior to studies that have focused on the inputs of the process. But innovations vary considerably both in terms of their nature - product as opposed to process - and their novelty. Baldwin and Da Pont (1996) demonstrate that the innovation regime-the extent to which R\&D is used, the types and sources of information, the use that is made of intellectual property rights - varies considerably by novelty of innovation. Simply categorizing firms as innovative or non-innovative risks aggregating different types of innovators in a way that may hide important relationships. Therefore, we investigate the extent to which the determinants of innovation differ across innovation types.

The paper is organized as follows. The survey data used for this study are described in Section 2. A description of the empirical model used for the analysis is provided in Section 3. Section 4 contains the results for the model that estimates the determinants of innovation for the Canadian manufacturing sector. The analysis is extended later in this section by estimating models for 
product and process innovation separately and examining the determinants of innovative activity by the novelty of the innovation. Finally, a conclusion is provided in Section 5.

\section{The Innovation Survey}

The data for this study come from the Survey of Innovation and Advanced Technology (SIAT). This survey was conducted by Statistics Canada in 1993 and was based on a frame of all firms possessing a Canadian manufacturing establishment. The frame was taken from Statistics Canada's Business Register. ${ }^{2}$ Firms were randomly sampled using strata that related to firm size (large versus small), region, and two digit-industry. The overall response rate to the survey was $86 \%$. For more details, see Appendix A.

The material collected in the survey covers a number of issues relating to the innovative and technological capabilities of Canadian manufacturing firms. The questionnaire for the survey consisted of five sections: a general section covering some basic characteristics of the firm; a section on research and development; a third section on innovation; a fourth section on intellectual property rights; and a final section dealing with advanced technology.

Because of the breadth of the survey, a firm's activity in the way of innovation, research and development and intellectual property protection can be linked together. This allows us to ask how research and development activity affects innovation and the extent to which firms that have learned to protect their intellectual property also tend to be more innovative. In addition, the survey investigates the extent to which firms have developed special competencies in technology, marketing and human resources and the extent to which these competencies, like those of a research and development capability, are related to innovation.

The survey also allows us to divide our population into different types of innovators - into those doing product or process innovations, and into those introducing world-first or less novel innovations.

\section{Empirical Model}

\section{The Model}

Firms innovate in the expectation of receiving an increase in profits due to innovation. The expected post-innovation return to innovation activity $r_{i}{ }^{*}$ for firm $i$ is taken to be a function of a set of firm-specific and industry-specific exogenous variables $\mathrm{x}_{\mathrm{i}}$. This may be formally expressed as:

$$
\mathrm{r}_{\mathrm{i}}^{*}=\mathrm{bx}_{\mathrm{i}}+\mathrm{u}_{\mathrm{i}}
$$

\footnotetext{
2 The Business Register maintains a listing of all establishments in the Canadian manufacturing sector.
} 
Even though $r_{i}{ }^{*}$ is not directly observable, we can observe whether firm i innovated or not. We assume that when the expected return from innovation is positive, firms innovate. The observable binary variable $I_{i}$ takes a value of one when the firm is an innovator and zero otherwise. Thus we can write

$$
\begin{array}{ll}
\mathrm{I}_{\mathrm{i}}=1 & \text { if } \mathrm{r}_{\mathrm{i}}^{*}>0 \\
\mathrm{I}_{\mathrm{i}}=0 & \text { otherwise }
\end{array}
$$

The expected return from innovation, given the characteristics of the firm and of the industry to which it belongs, is

$$
\begin{aligned}
\mathrm{E}\left(\mathrm{r}_{\mathrm{i}}^{*} \mid \mathrm{x}_{\mathrm{i}}\right) \text { gives us } \operatorname{Prob}\left(\mathrm{I}_{\mathrm{i}}=1\right) & =\operatorname{Prob}\left(\mathrm{u}_{\mathrm{i}}>-\mathrm{bx}_{\mathrm{i}}\right) \\
& =1-\mathrm{F}\left(-\mathrm{bx}_{\mathrm{i}}\right)
\end{aligned}
$$

where $\mathrm{F}$ is the cumulative density function for the residuals $\mathrm{u}_{\mathrm{i}}$. The choice of the statistical model depends on assumptions about the form of the residuals $u_{i}$. If the cumulative distribution of residuals is normal, the probit model is the appropriate choice; if it conforms to a logistic function, the logit model is appropriate. For practical purposes, the difference between the results of the two models is usually small. The logit model will be used for our analysis.

Differences in expected profits from innovation and, therefore, differences in profitability are hypothesized to be related to differences in firm size, market structure, appropriability conditions, technological opportunities, demand conditions, and R\&D activity. ${ }^{3}$

\section{Dependent Variable}

Innovation surveys allow us to examine the determinants of the output of the innovative process. In that respect, they differ from previous studies using R\&D expenditures (Levin and Reiss, 1984) or patents (Pakes and Griliches, 1984). Innovation surveys ask whether a firm has produced an innovation and then proceed to explore the various firm and industry characteristics associated with the innovation.

Innovation in the 1993 Canadian innovation survey refers to the use of an invention for either the production of a new product or process, or the improvement of an existing product or process. Changes that are purely aesthetic or involve minor design alterations are not considered to be innovations. Evidence from the 1993 survey indicates that some 35\% of Canadian manufacturing firms were innovative (Baldwin, 1997a).

Innovations differ in several aspects. They vary both in nature-product or process - and importance - radical or imitative. A product innovation is the commercial adoption of a brand new product or an existing product of higher quality. A process innovation is the use of new or improved production methods that lead to a reduction in unit production costs. Often product and

\footnotetext{
3 See Cohen (1996) for a review.
} 
process innovations occur simultaneously since the production of a new product may require a new or improved production method.

Some 35\% of large innovative Canadian manufacturing firms in the 1993 survey introduced a product-only innovation; while $45 \%$ introduced a process-only innovation; and $46 \%$ introduced a combined product-process innovation.

Innovations also vary in terms of novelty. In a study of innovation in the Netherlands, Kleinknecht, Reijnen, and Smits (1992) found that only 3.6\% of innovations were totally new, $49.2 \%$ were modestly improved and $41.3 \%$ involved simply a product differentiation. In a related U.S. study done for the Small Business Administration, over $85 \%$ of innovations were classified as being modest improvements designed to update existing products; less than $12 \%$ involved significant innovations (Audretsch, 1995, Table 2.7).

Innovations developed or adopted by Canadian firms can be classified into three groups - worldfirsts, Canada-firsts and other types of innovations. World-first innovations refer to leading edge innovations that are the first of their kind in the world. Canada-first innovations are those that have been developed outside of Canada and introduced for the first time in Canada. 'Other' types of innovations refer to innovations that are new to a particular firm but not new in Canada. Fifteen percent of all innovations reported by Canadian firms in the 1993 survey were world-first innovations compared to 30\% for Canada-first innovations (Baldwin and Da Pont, 1996). The remainder $(55 \%)$ were innovations that were new to the firm, but were neither Canada-firsts nor world-firsts.

In order to test the sensitivity of our results to alternative definitions, innovation is measured with three different dependent variables in this paper. First, the incidence of innovation is captured by a dichotomous variable that measures whether or not firms have introduced an innovation of any type within three years prior to the survey date of 1993. The binary variable takes a value of one for innovative firms, and zero for non-innovative firms.

Second, the product/process distinction is captured by a set of three binary variables. The first variable takes a value of one if a firm produced only product innovations and zero if the firm has not produced any innovations of any type. The second binary variable contrasts process-only innovators against non-innovators, while the third contrasts combined product/process innovators against non-innovators.

Third, a set of binary variables is constructed to capture novelty effects - world-first innovators versus non-innovators; and Canada-first innovators versus non-innovators; and 'other' innovators versus non-innovators. 


\section{Explanatory Variables}

Innovation is highly idiosyncratic. Firms are heterogeneous. Some of the differences in innovative capabilities will be related to differences in industry environment while others are attributable to differences in innovative tendencies of individual firms. Therefore, innovation is postulated here to be a function of both firm-specific and industry-specific variables. Firmspecific variables include characteristics variables - such as firm size, and ownership - and activity variables - such as R\&D and patenting. Industry-specific variables include competition and technological opportunity.

\section{Firm Characteristics}

\section{Size}

A measure of firm size is included to test whether there are inherent advantages associated with size. Large firms, it is often argued, tend to be more innovative than their smaller counterparts. Reasons for this include scale advantages of large firms; a greater likelihood to engage in risky projects; and economies of scope (Cohen, 1996). Larger firms have easier access to financing, can spread the fixed costs of innovation over a larger volume of sales and may benefit from economies of scope and complementarities between R\&D and other manufacturing activities. Counter arguments, however, exist to suggest that as firms grow large, their R\&D becomes less efficient. Levin and Reiss (1988) reviewed the empirical evidence and observed that it was inconclusive. ${ }^{4}$ Economies of scale and scope may exist, but may be exhausted long before a firm becomes very large.

Size is measured here by the total number of employees in a firm, including both production and non-production workers. Firms are classified as belonging to one of three size categories-less than 100 employees, 100 to 499 employees, and 500 employees or more. Based on this, three binary variables have been constructed to capture size effects.

\section{Nationality of Ownership}

Canada, because of its size and proximity to the United States, has a mixture of both Canadianowned and foreign-owned firms. Existing studies, relying on R\&D intensity, are inconclusive as to whether or not the nationality of ownership of a firm has an impact on its innovative activity. Caves et al. (1980, p. 193) suggest that foreign activity reduces the rate of R\&D activity in Canada. However, lower R\&D intensity may not signify less innovation if multinational subsidiaries import innovations from their parents. Using a survey for a limited number of firms in five industries, De Melto et al. (1980) reported that foreign firms operating in Canada were

\footnotetext{
${ }^{4}$ The recent research as reviewed by Cohen and Levin (1989) tends to regard the failure of the empirical literature to obtain robust results on how innovation is related to size of firm and to market structure as an indication that these relationships are more complex than previously believed.
} 
less R\&D intensive than their domestic counterparts, but that they accounted for a disproportionately large percentage of process innovations.

In order to confirm this finding for the manufacturing sector as a whole, a binary variabletaking a value of one if the firm is foreign-owned, and zero otherwise - is included to investigate whether foreign-controlled firms are more likely to be innovative.

\section{Competencies}

While size is often used as a proxy for scale effects, it also is a proxy for differences in internal competencies of firms. Large firms do not differ from small firms in that they are simply scaledup versions of the latter, a requirement if size captures only scale effects. Scale economies refer to differences that arise from an equal percentage increase in all factors. However, large firms use factors in very different proportions than small firms. Their capital/labour ratios are generally higher. The production process is very different between large and small firms as technology use for the two groups is not the same (Baldwin and Sabourin, 1995). Large firms are not only more likely to adopt an advanced technology but they also combine greater numbers of advanced technologies. The observed differences between large and small firms come from a host of factors that change as firms grow.

Few economic studies consider many firm-specific competencies, outside of $\mathrm{R} \& \mathrm{D}$, as contributing factors to innovation. Yet, over time, firms build up a set of competencies that are crucial for their overall growth and development. Those firms best able to develop certain key competencies relating to innovation might be expected to be more innovative. In a recent study, Baldwin and Johnson (1995) use data from a survey of small and medium-size businesses and find that more-innovative firms place a greater emphasis on marketing, finance, production, and human resource competencies than do less-innovative firms. It is, therefore, important to include a measure of the extent to which a firm has developed key capabilities in areas crucial for the implementation of a successful innovation strategy.

A set of questions on the 1993 Innovation Survey allow us to examine the extent to which innovation is associated with greater competencies in a number of areas. Firms are asked to indicate the importance that they give to various marketing, technology, production, and human resource strategies. Competency variables are constructed from the firms' responses to this set of questions. Each question is scored on a scale from 1 (not important) to 5 (crucial). For market strategy, three questions are used - the extent to which a firm introduced new products in present markets, current products in new markets, or new products in new markets. Under technology strategy, three are also used-the importance of developing new technology, improving technology developed by others, and improving on their own existing technology. For production strategy, four factors are used-using new materials, using existing materials more efficiently, improved inventory control and improved process control. Under human resource strategy, two factors are used - whether a firm values continuous staff training, and whether it uses innovative

remuneration schemes. For intellectual property rights strategy, the importance of improving intellectual property management is used. 
The answers to these questions are used to capture the emphasis given to a particular area or the importance of this input to the production function. ${ }^{5}$ An aggregate score for each of the strategies was constructed by summing the scores of their individual strategies. For example, the sum of the scores of three factors - the importance of developing new technology, improving technology developed by others, and improving on their own existing technology-was used for the aggregate score for technology strategy. Since the number of factors varies across strategies, the results were standardized to correct for this. ${ }^{6}$

An alternative approach is to use principal component or factor analysis to define a set of competency variables from the firm scores in the areas of marketing, technology, and production strategies. This was tried and it was found that stories told by the data were similar. Since the former approach is easier to interpret, it is used in this analysis.

\section{Firm Activities}

\section{Research and Development}

Although neither a necessary nor a sufficient condition for innovation (Äkerblom, Virtaharju and Leppäahti, 1996; Baldwin, 1997b), R\&D is an important input into the innovation process. ${ }^{7}$ Firms that have established an effective R\&D program are more likely to innovate for several reasons. First, R\&D directly creates new products and processes. Second, firms that perform R\&D are also more receptive to the technological advances made by others (Mowery and Rosenberg, 1989). A binary variable was constructed to capture this effect, taking a value of one if the firm engages in $R \& D$, zero otherwise.

\section{Appropriability and Intellectual Property Rights}

Firms commercialize new products and processes expecting, in return, certain rewards - usually an increase in profits. If inventions are easily copied by competitors, there is little incentive to innovate. To protect their innovation from being copied, firms use various forms of intellectual property protection, such as patents, trade secrets, copyrights, and trademarks.

Despite the widespread belief that the existence of intellectual property protection is critical to the innovative process, empirical evidence as to the beneficial effects on innovative activity is sparse (Cohen, 1996). Indeed, there is empirical evidence to suggest the opposite. In a study examining the effectiveness of patents in protecting intellectual property rights, Mansfield (1986) found that only in the pharmaceutical and chemical industries did patents play an important role. Levin et al. (1987) also found that product patents were more important for pharmaceuticals and

\footnotetext{
${ }^{5}$ While these are subjective questions, they have been used in previous surveys with success (Baldwin, Chandler et al., 1994; Johnson, Baldwin and Hinchley, 1997).

${ }^{6}$ This was done by averaging the scores within each category.

${ }^{7}$ Baldwin (1997b) reports that only 56\% of firms conducting ongoing R\&D reported a product or process innovation, while only $49 \%$ of firms with a product or process innovation reported that they had an ongoing R\&D program.
} 
chemicals. Moreover, Levin et al. (1987) found that other forms of intellectual property rights protection were perceived by firms to be more effective than patents. Complementary marketing activities and lead-time were found to be the most effective in protecting product innovations. For process innovations, patents were found to be much less effective, while secrecy was found to be the most effective instrument. Cohen (1996) concluded that, although there is evidence of inter-industry differences in appropriability conditions, there was little empirical evidence as to the beneficial effect of these conditions on innovative activity across a wide range of industries.

Other studies have tended to define appropriability at the industry level. We choose to move to the level of the firm, because there is evidence that shows firms, even within well-defined industries, are idiosyncratic when it comes to their tendency to develop a capacity to protect their ideas. Appropriability will be partially conditioned by the nature of the industry - whether the product is sufficiently definable that it can be patented. But, even within industries where patents are generally not used, there will be some firms that develop a strategy of intellectual property protection. They make appropriability work. Appropriability may partially be exogenous in that it stems from some inherent product characteristic that varies considerably across industries, but a substantial part of the appropriability environment stems from individual decisions taken at the firm level to develop product characteristics that are patentable, or legal expertise in finding ways of protecting what otherwise might not be protected.

Three binary variables have been constructed to estimate appropriability effects on innovation. They are based on whether or not a firm uses patents, uses trade secrets, or uses any other intellectual property right (trade marks, copyrights, industrial designs) to protect its innovations. This is a direct measure of the extent to which the firm found these to be important, or the degree to which it was able to devise a strategy to protect its intellectual property. Learning how to do this is not straightforward and requires the development of specific competencies-legal skills, design skills, marketing and service skills. Each variable takes a value of one if the particular property right is used and a value of zero if it is not.

We also experimented with an alternative variable to capture the intellectual property regime of a firm. We used the score (on a scale of 1 -not very effective - to 5-extremely effective) that a firm gave to the efficacy of patents, trade secrets and other intellectual property rights as a means of protecting its innovation. This effectiveness variable provides a measure that does not depend upon past activity - that is, while the patent-use variable at the firm level reflects both past innovative activity and its attitude towards intellectual property right protection, its skill in protecting intellectual property (represented by the patent-effectiveness variable) is a more direct measure of existing attitudes towards the value of patent protection - though existing attitudes are, of course, conditioned by past innovative activity and experience with the effectiveness of intellectual property rights.

Although we experimented with this efficacy variable, we chose not to focus our results on it for two reasons. First, fewer firms answered this question and those who did so were not representative. Firms that answered this question were much more likely to have taken out a patent. Therefore, average scores at the industry level using this variable really reflected differences in the propensity to patent - the variable that is used here at the plant level. Second, a 
regression of the average score on the efficacy to patent shows a strong relationship to the propensity to patent (Baldwin, 1997a). Since the patent-efficacy score was capturing the propensity to patent and there were far more observations on the latter that represented a broader set of firms in the overall population, the propensity to patent variable is used here.

\section{Industry Effects}

\section{Technological Opportunities}

Technological opportunities differ across industries since the scientific environment provides more fertile ground for advances in some industries than others. As a result, the technical advance generated per unit of R\&D is greater in some industries than others (Cohen, 1996).

Two proxies that were suggested by Levin et al. (1987) have been used in various studies. ${ }^{8}$ The first is a measure of the extent to which an industry relies on science-based research; while the second measures the extent to which an industry relies on external sources of knowledge, such as customers and suppliers, for technological advance. In this study, we use the first approach, believing that it comes closer to the concept of the advanced scientific knowledge base that is available to a firm. The second is more a function of the extent to which knowledge flows from firm to firm and represents the extent to which knowledge is easily transferable rather than differences in the underlying scientific environment.

To capture the first concept, technological opportunity is measured here by the percentage of R\&D performers within an industry that have collaborative R\&D agreements with universities, colleges or external R\&D institutions.

\section{Competitive Conditions}

Firms active in highly concentrated markets have been hypothesized to be more likely to innovate. Monopoly power, it is claimed, makes it easier for firms to appropriate the returns from innovation and provides the incentive to invest in innovation. However, this view is far from universal. Others (Arrow, 1962) have argued that the gains from innovation at the margin are larger in an industry that is competitive than under monopoly conditions. Moreover, insulation from competitive pressure can breed bureaucratic inefficiency (Scherer, 1980). Finally, if market structure is largely determined by the life-cycle of an industry and an industry is more atomistic in the early stages of the life cycle ${ }^{9}$ when innovation is more intensive, we should expect innovation to be higher when markets are less concentrated. ${ }^{10}$

\footnotetext{
${ }^{8}$ Sterlacchini (1994) uses the percentage of those firms investing in R\&D that have collaborative projects with universities. Arvanitis and Hollenstein (1994) use the extent to which outsiders like competitors and customers contributed to the innovation.

${ }^{9}$ For a discussion of the relationship between innovation and structure, see Abernathy and Utterbach (1978), Rothwell and Zegveld (1982), Gort and Klepper (1982) and Klepper and Millar (1995), Klepper (1996).

${ }^{10}$ See also Acs and Audretsch (1991).
} 
The earlier empirical evidence on the relationship between concentration and innovation is mixed (Cohen and Levin, 1989). The recent research has recognized that the post-innovation market structure, rather than simply being an exogenous determinant of innovation, is more likely to be an endogenous (simultaneous) outcome of dynamic growth of innovating firms under favourable appropriability conditions (Levin and Reiss, 1984, 1988; Cohen and Levinthal, 1989).

Since the intrinsic concept that we want to measure is the degree of competition faced and concentration is a poor proxy for this (Baldwin and Gorecki, 1994), we choose to measure the potential competition that a firm faces by the number of competitors that the firm tells us it faces. Firms are grouped according to whether they face five or fewer competitors, six to 20 competitors, or more than 20 competitors. Three binary variables are used to capture these competitive categories.

The variables that are used are listed in Table 1.

\section{Estimation Procedures}

Our model consists of two equations - one for innovation and one for appropriability conditions (represented here by patent use):

$$
\begin{aligned}
\text { INNOV } & =\alpha_{0}+\alpha_{1} * \text { SizE }+\alpha_{2} * \text { COMP }+\alpha_{3} * \text { R } \& D+\alpha_{4} * \text { APPRoP } \\
& +\alpha_{5} * \text { TECH-OPP }+\alpha_{6} * \text { FirM-STRATEGIES }(\text { TeCH-STR, MRKT-STR, PROD-STR })+\varepsilon_{1} \\
\text { APPROP } & =\beta_{0}+\beta_{1} * \text { SIZE }+\beta_{2} * \text { COMP }+\beta_{3} \text { TeCH-OPP }+\beta_{4} * \text { ForeIGN } \\
& +\beta_{5} * \text { INNOV }+\beta_{6} * \text { IP-STR }+\varepsilon_{2}
\end{aligned}
$$

These equations contain two variables that we treat as endogenous-innovation (INNOV) and appropriability (APPROP) - and a number of exogenous variables. INNOV is a binary dependent variable indicating whether or not a firm is innovative. SizE is the employment size of a firm, while FOREIGN measures whether a firm is controlled from abroad. FIRM-STRATEGIES measure the competencies of a firm. The firm strategies that are included in the innovation equation are TECH-STR, which measures the importance a firm attributes to improving its technology; MRKTSTR, which measures the importance to a firm of marketing new products and penetrating new markets; PROD-STR, which measures the importance of a progressive production strategy. The firm strategy variable that is included in the appropriability equation is IP-STR, which measures the importance that a firm attributes to intellectual property management. Two industry variables have been included in the analysis - technological opportunity (TECH-OPP), which is a measure of the prevalence of basic science within an industry, and competition (COMP), which is the number of competitors a firm faces. Finally, two activity variables have also been included. R\&D measures whether a firm engages in R\&D activity. Intellectual property rights management (APPROP) measures the use of patents.

Three issues arise in choosing the estimation procedure because of problems associated with the use of a dichotomous dependent variable, simultaneity, and the use of survey data. 
Table 1. Description of Dependent and Explanatory Variables for Logit Model

\begin{tabular}{|c|c|}
\hline Variable & Description \\
\hline DEPENDENT & \multirow[b]{2}{*}{ Innovator or non-innovator } \\
\hline $\begin{array}{l}\text { Innovation } \\
\text { INNOV }\end{array}$ & \\
\hline \multicolumn{2}{|l|}{ EXPLANATORY } \\
\hline FIRM CHARACTERISTICS & \multirow{6}{*}{$\begin{array}{l}\text { Employment Size } \\
\text { - Less than } 100 \text { employees } \\
\text { - } 100 \text { to } 499 \text { employees } \\
\text { - } 500 \text { or more employees }\end{array}$} \\
\hline Size & \\
\hline ENTSIZE1 & \\
\hline ENTSIZE2 & \\
\hline ENTSIZE3 & \\
\hline Ownership & \\
\hline FOREIGN & \multirow[t]{2}{*}{ Canadian or foreign owned } \\
\hline Strategies & \\
\hline TECH-STR & \multirow{4}{*}{$\begin{array}{l}\text { Technology strategy } \\
\text { - Importance of developing and improving technology } \\
\text { Marketing strategy } \\
\text { - Importance of new products and new markets } \\
\text { Production strategy } \\
\text { - Importance of new materials and improving inventory/process control } \\
\text { Intellectual Property Management strategy } \\
\text { - Importance of intellectual property management }\end{array}$} \\
\hline MRKT-STR & \\
\hline PROD-STR & \\
\hline IP-STR & \\
\hline FIRM ACTIVITIES & \\
\hline R\&D Activity & \multirow{2}{*}{ R\&D performer or not } \\
\hline $\mathrm{R} \& \mathrm{D}$ & \\
\hline Intellectual Property Rights & \multirow{4}{*}{$\begin{array}{l}\text { Use of patents } \\
\text { Use of trade secrets } \\
\text { Use of other measures - copyrights, trademarks, industrial designs }\end{array}$} \\
\hline PATENTS & \\
\hline TRADSECR & \\
\hline OTHIPROP & \\
\hline INDUSTRY CHARACTERISTICS & \multirow{6}{*}{$\begin{array}{l}\text { Number of Competitors } \\
\text { - Five or fewer competitors } \\
\text { - Six to } 20 \text { competitors } \\
\text { - More than } 20 \text { competitors }\end{array}$} \\
\hline Competition & \\
\hline COMP1 & \\
\hline COMP2 & \\
\hline COMP3 & \\
\hline Technological Opportunity & \\
\hline TECH-OPP & Technological opportunity \\
\hline
\end{tabular}

\section{Dichotomous Dependent Variable}

The dependent variable that is used for the innovation equation is a binary variable. Because of this, we use a logit regression. Use of ordinary least squares in this situation gives rise to several problems. First, OLS regressions will have a heteroscedastic error term. This will produce estimates that are still unbiased but are inefficient. Generalized least squares can handle the problem associated with heteroscedasticity. However, the predicted values do not necessarily fall within the range 0 to 1 . It has, therefore, become the practice to use probit and logit analysis for estimating binary dependent variables even though the heteroscedasticity problem can be handled with a generalized least squares methodology. ${ }^{11}$

\footnotetext{
${ }^{11} \mathrm{We}$ also performed OLS and GLS and simultaneous regressions. The qualitative results were exactly those that are reported here.
} 


\section{Survey Data}

The data used for the analysis come from a survey that randomly samples a population that was stratified by region, industry and size. Multivariate analysis of this data, if it is to represent the behaviour of the population, needs to take into account the sampling weights attached to each observation.

With perfect specification of the variables that should be included in the innovation relationship, as well as perfect specification of the functional form, unweighted results will be the same as weighted results. Since it is unlikely that we can meet the rigid conditions for relying completely on the unweighted results, we experimented with both routes. The formulation that is reported herein produces quite similar results for both. We arbitrarily chose to report the weighted results here.

\section{Simultaneity}

Innovation is taken to be a function of the extent to which a firm can appropriate the benefits of innovating - as measured by its use of patents - as well as a set of firm-specific and industryspecific characteristics. Firms that can effectively protect their innovations- through the use of patents, trade secrets or other forms of intellectual property rights - are expected to have a greater likelihood of being innovative. They are more likely to have established capable legal departments for handling patent applications, or perhaps their organization is better suited for preventing the disclosure of trade secrets.

Patent use, on the other hand, is likely to be a function of innovation and a set of firm-specific and industry-specific characteristics. Once an innovation is discovered, a firm may turn to patents to protect its innovation from being imitated.

Innovation and appropriability are, therefore, not independent of each other. Because of this, using a single equation model can lead to biased and inconsistent estimates. The use of a simultaneous equation model is used to address this difficulty.

Our approach is to use a two-stage procedure within the logistics framework to estimate a simultaneous relationship. We also experimented with a simultaneous probit model and found the results to be qualitatively almost identical.

There are other variables in the innovation model such as R\&D that are not endogenous but that may not be independent of the error term. In particular, fixed effects at the firm level may result in a lack of independence between the error term and R\&D. This occurs if there are distinct characteristics of firms that are not captured in the variables of the model but that are correlated with R\&D. This is likely to be the case because there is evidence that innovators do many things more intensely than non-innovative firms. They not only are more likely to have an R\&D unit, but they also place greater stress on many other strategies (Baldwin and Johnson, 1998). In this case, the inclusion of only one of these activities, such as R\&D, will capture not only its own effect but also all the other activities that accompany R\&D in a more-innovative firm. This 
problem is dealt with here with the inclusion of a number of competency variables that not only are key to the innovation process, but that also serve to capture the component of the error term that is correlated with R\&D capabilities in equation 1.

\section{Regression Results}

\section{Incidence of Innovation}

The results of the regression models for the probability of a firm being innovative are given in the first three columns of Table 2. The first column reports the weighted single equation logit estimates. The third column reports a simultaneous logit model with a slightly reduced set of variables - only patents are included under intellectual property. The second column is a single equation logit with the same set of variables as are included in the simultaneous logit model. These regressions are estimated against an excluded firm that is small and faces few competitors. All results are for large firms only, those firms that are found in the profiled set of firms in Statistics Canada's Business Register. ${ }^{12}$

The results in Table 2 provide estimates of the coefficients in the logit model. These coefficients provide only qualitative guides for the effects of each variable. The associated probabilities attached to each variable for the simultaneous model are provided in Table $3 .^{13}$

R\&D activity and firm size have the greatest impact on innovation, regardless of the model used. Firms not performing R\&D have only an $11 \%$ probability of innovating. Firms conducting R\&D have a $41 \%$ probability of innovating. This accords with other studies (Cohen and Klepper, 1996a; Baldwin, 1997b). ${ }^{14}$ Similarly, the largest firms have a significantly higher probability of being innovative $(68 \%)$ than do either small or medium-sized ones $(30 \%)$. No significant difference is found, however, between small and medium-sized firms in terms of their likelihood of being innovative.

Nationality of ownership was included in the first round of estimates but it was found to have no significant effect on the probability that a firm is innovative and was subsequently omitted from the final results. It should be noted that nationality does become significant if size or R\&D is omitted. Foreign-owned firms are larger and are more likely to perform R\&D; but once these factors are taken into account, there is no additional effect of nationality on innovation.

\footnotetext{
${ }^{12}$ Only these firms were asked all of the questions about the variables used in the analysis. The sample used in the regression consists of 1,253 observations out of a total of 1,593 in the survey who answered all of the questions used in the analysis. The proportion of the total that was accounted for by this group was about the same across the strata used in the survey - that is, they are broadly representative of the sample.

${ }^{13}$ Probabilities (p) are estimated using the logit equation: $\mathrm{P}=\exp (\beta \mathrm{x}) /[1+\exp (\beta \mathrm{x})]$

${ }^{14}$ When R\&D is broken down into those doing R\&D occasionally and those doing it continuously, the probability of innovating for occasional R\&D performers is 37\%, while the probability of innovating for continuous performers is $54 \%$. Brouwer and Kleinknecht (1996) also report that in Holland, firms with continuous R\&D facilities have a higher probability of innovating.
} 
Technological opportunity is a statistically significant determinant of innovation. The probability of being an innovator increases from $28 \%$ at the mean of this variable minus one standard deviation to $40 \%$ at the mean plus one standard deviation. Firms in industries relying on sciencebased research are more likely to be innovative. This finding corroborates other research that reports that there are greater opportunities for innovation in industries for which basic science is important (Arvanitis and Hollenstein, 1994; Crépon et al., 1996).

The most striking result is the difference in the sign attached to the appropriability variable in the single equation model and in the simultaneous equations model. In the single equation model (column 2), that has the same specification as the simultaneous model, use of patents is positively related to the probability of being an innovator. In contrast, the patent variable is negatively related to innovation in the simultaneous model. We conclude that the impact of appropriability conditions on innovation will be incorrectly represented if endogeneity issues are not taken into account.

Several of the competency variables that both proxy other inputs to the innovation process and handle firm fixed effects are highly significant. The emphasis that is placed on technology and marketing strategy are both positively related to innovation and highly significant. In each case, the probability of innovating increases by about 20 percentage points going from the mid 20 's to the mid 40's as the competency variable increases from its mean value minus one standard deviation to its mean plus one standard deviation. Firms that place more emphasis on their technology strategy are more likely to innovate. As Mowery and Rosenberg (1989) emphasized, $R \& D$ is not the only important input into the innovation process. Firms that stress the capacity to market new products and target new markets for existing products are also more likely to innovate. Conversely, the incidence of innovation is found to be negatively related to the emphasis that a firm places on production strategy. Firms that stress the importance of using new materials and improving inventory and process control are less likely to innovate. This suggests that an emphasis on cost cutting is a substitute to innovating for some firms. The emphasis on human resources was not found to be significantly related to the probability of innovation and has been excluded.

Innovation is also significantly related to the number of competitors that a firm faces, but the relationship is not monotonic. Firms facing moderate competition - six to 20 competitors-are significantly more likely to innovate. Firms facing the stiffest competition-more than 20 competitors - are the least likely to do so. Firms with six to 20 competitors have a $42 \%$ probability of being innovators. Firms in the most atomistic group have only a $26 \%$ chance of innovating.

Various alternatives were tried in order to test whether these results are affected by other specifications of the innovation equation. First, we moved to the industry level to define appropriability conditions. That is we defined the environment in which the firm operated as being determined by the average 2-digit industry patent use. This has two effects. First, it means that the environment is more likely to be exogenous and, therefore, the need for a simultaneous equations framework is less pressing. Secondly, it overcomes the criticism that the use of patents at the firm level may reflect not so much how a firm engineers its intellectual property 
environment as its past innovation success. However, when patent use is included at the industry level, it is found to be insignificant.

Table 2. Determinants of Innovative Activity (Company Weighted)

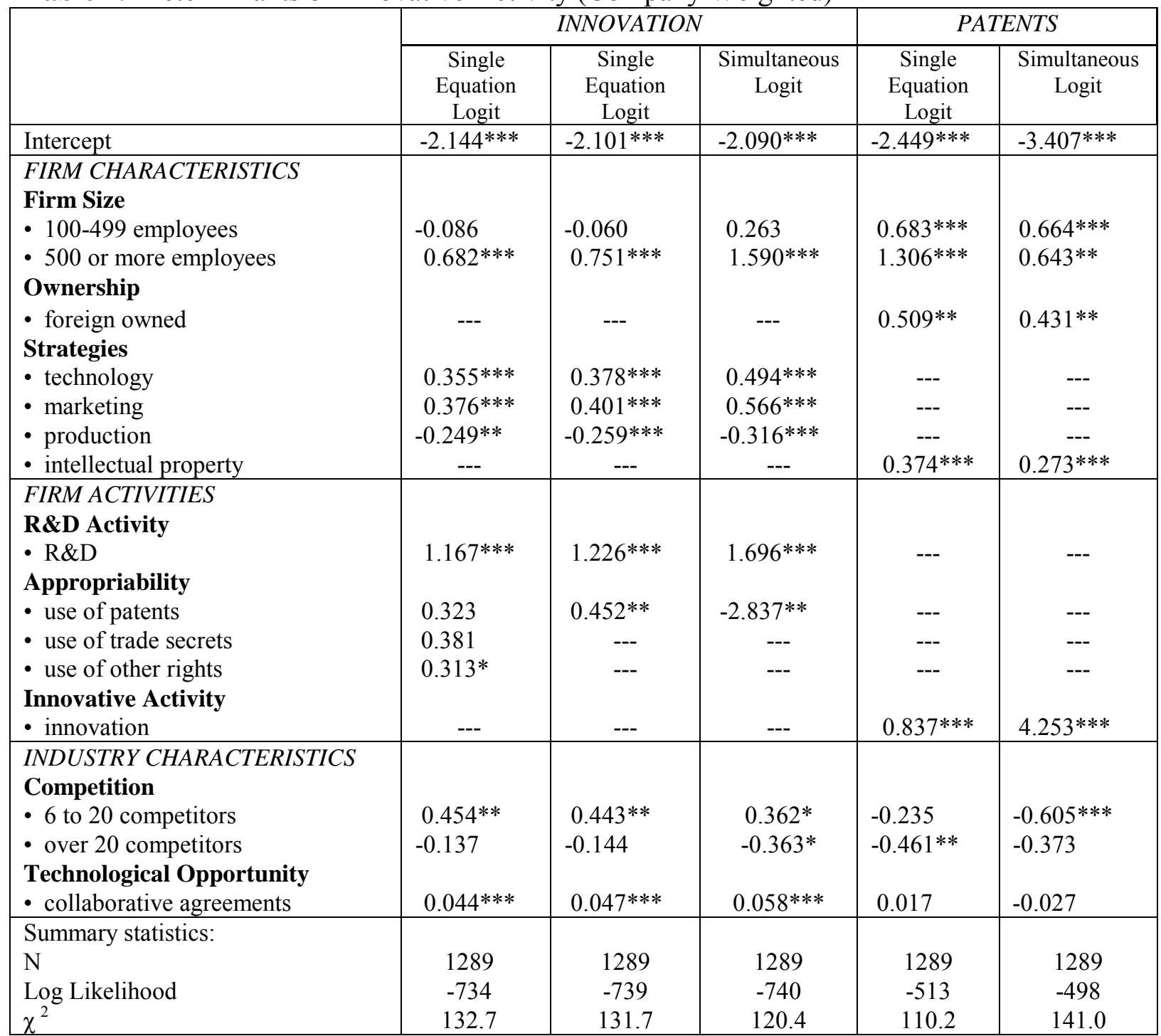

Note: *** significant at the $1 \%$ level; ** significant at the $5 \%$ level; * significant at the $10 \%$ level.

We also experimented with an alternative measure of the importance of the intellectual property environment - the score (from 1-not very effective - to 5-extremely effective) that the firm gave to the effectiveness of various instruments in 'preventing competitors from bringing to market copies of its new product or process technology'. The instruments considered included seven formal options - copyrights, patents, industrial design, trade secrets, trade marks, integrated circuit designs and plant breeders' rights. In addition, the scores given to other strategies - complexity of product design, being first in the market - were included. When the average scores for patents, trade secrets and other strategies are included at the 2-digit industry level, the patent score is insignificant, but the score on trade secrets is positive and significant. In 
industries where trade secrets are seen to be effective, the probability that innovation occurs is higher. When patent and trade secret use, as well as the efficacy variables, are included, the use variables remain insignificant, but both the efficacy scores given to trade secrets and other strategies (product complexity and trade secrets) remain positive and significant.

Industry effects were also included. For this purpose, we broke our sample down into three broad groups that differ in terms of the innovation intensity of the industry. Industries are classified to one of three groups based on the classification system used by Robson et al. (1988), who investigated differences in innovative tendencies of 2-digit industries. The first class used here produces the most innovations and tends to disseminate more innovations than they use to the other two groups of industries. The first group includes electrical and electronic products, chemicals and chemical products, machinery, and refined petroleum and coal. The second group produces fewer innovations and does less dissemination. It consists of transportation equipment, rubber products, non-metallic mineral products, plastics, fabricated metals and primary metals. The last group of industries produces the least number of innovations and tends to use innovations produced in the first two sectors. The third group of industries consist of textiles, paper, wood, clothing, leather, beverages, food, furniture and fixtures, and printing and publishing. When we include binary variables for these three classifications, very little changes. Thus, the inclusion of broad industry effects, which we know are associated with innovation tendencies, does not affect our results.

We also estimated the innovation equation using efficacy scores on intellectual property at the firm level. The sample for which these scores are available is considerably smaller than that for which patent and trade secret use is available. Indeed, using the smaller sample, if we calculate the same regression using intellectual property use as is reported in column 2 of Table 2, patent use becomes insignificant. However, in this formulation, strategies relating to complexity of product and lead-time are significant - much as they are in the equation that summarizes these at the industry level.

We also included the score given to whether a firm gets its innovative ideas from its competitors or from its customers. While Arvanitis and Hollenstein (1996) have included a variant of this variable to capture the presence of technological opportunities, it also could approximate conditions under which information flows are easily transmitted and difficult to protect. This hypothesis is confirmed by its negative coefficient in the formulation that includes it.

In summary, the results of these various experiments suggest that appropriability stimulates innovation. But it is not patents that matter, so much as trade secrets and other strategies that allow a firm to appropriate the fruits of its investments in intellectual capital. ${ }^{15}$ Moreover, in industries where ideas are easily taken from competitors or transferred from others, innovation is less likely.

\footnotetext{
15 Schankerman (1991) provides evidence that at least 75 percent of the private returns to inventive activity are obtained from sources other than patents.
} 
Table 3. Estimated Probability of Introducing an Innovation and Using Patents for Simultaneous Logit Model

\begin{tabular}{|c|c|c|}
\hline & Innovation & Patent Use \\
\hline \multicolumn{3}{|l|}{ FIRM CHARACTERISTICS } \\
\hline \multicolumn{3}{|l|}{ Firm Size } \\
\hline 1 to 99 employees & 30 & 13 \\
\hline 100 to 499 emplyees & 30 & 23 \\
\hline 500 or more employees & 68 & 23 \\
\hline \multicolumn{3}{|l|}{ Ownership } \\
\hline Foreign & --- & 22 \\
\hline Domestic & --- & 15 \\
\hline \multicolumn{3}{|l|}{ Strategies } \\
\hline Technology & 34 & --- \\
\hline+ standard deviation & 45 & --- \\
\hline - standard deviation & 24 & --- \\
\hline Marketing & 34 & --- \\
\hline+ standard deviation & 46 & --- \\
\hline - standard deviation & 23 & --- \\
\hline Production & 34 & --- \\
\hline+ standard deviation & 27 & --- \\
\hline - standard deviation & 41 & --- \\
\hline Intellectual Property & --- & 16 \\
\hline+ standard deviation & --- & 20 \\
\hline - standard deviation & --- & 13 \\
\hline \multicolumn{3}{|l|}{ FIRM ACTIVITIES } \\
\hline \multicolumn{3}{|l|}{ R\&D Activity } \\
\hline$R \& D$ performer & 41 & --- \\
\hline Non performer & 11 & --- \\
\hline \multicolumn{3}{|l|}{ Appropriability } \\
\hline Patent user & 5 & --- \\
\hline Non user & 45 & --- \\
\hline \multicolumn{3}{|l|}{ Innovation } \\
\hline Innovator & --- & 72 \\
\hline Non innovator & --- & 4 \\
\hline \multicolumn{3}{|c|}{ INDUSTRY CHARACTERISTICS } \\
\hline Number of competitors & & \\
\hline Zero to 5 & 33 & 19 \\
\hline 6 to 20 & 42 & 12 \\
\hline Over 20 & 33 & 19 \\
\hline \multicolumn{3}{|l|}{ Technological Opportunity } \\
\hline Technological opportunity & 34 & 16 \\
\hline + standard deviation & 40 & 16 \\
\hline - standard deviation & 28 & 16 \\
\hline
\end{tabular}




\section{Patent Use $e^{16}$}

Patent use is strongly related to whether a firm is an innovator. It also is a function of whether the firm has a well-developed intellectual property strategy. But the former has a much greater effect on the probability of patent use (Table 3).

Patent use is strongly related to innovative activity, irrespective of whether the single equation or the simultaneous equations framework is used. This is in marked contrast to the case for the innovative-activity variable. Firms that innovate are more likely to patent. ${ }^{17}$ But firms that have developed an intellectual property strategy that allows them to appropriate the fruits of their innovation via the patent system or firms that value patents highly are no more likely to innovate.

Both innovation and patent use are related to size. But the effect of size on the probability of patent use is much less than on innovation (Table 3). Beyond that, there are few other similarities. First, patent use but not innovation is related to the nationality of the firm. Foreignowned firms are more likely (22\% compared to $15 \%$ for domestic firms) to protect their innovation with patents, though they are not significantly more likely to innovate. More competition leads to more innovation (at least for a modest increase in competition) but it leads to less patenting. Technological opportunity leads to more innovation but has no significant effect on the likelihood that patents will be pursued.

\section{Type of Innovation}

Innovations are commonly categorized as being one of two types-product or process. Product innovations involve the introduction of a new product or the increase in quality of an existing product, while process innovations tend to reduce production costs.

Dividing innovations into two mutually exclusive categories such as product and process innovations is difficult to do. In many cases, innovations involve simultaneous changes in both products and processes. In order to investigate whether differences exist in the determinants of innovation, we divide innovations into three groups - product innovations where there has been no change in manufacturing technology (what we shall call product-only innovations), product innovations where there has been a simultaneous change in manufacturing technology (what we shall call combined product/process innovations), and process innovations where there has not been a product change (what we shall call process-only innovations). The parameter estimates of the logit regressions for each of these innovation-types are reported in Table 4. The probability values associated with the simultaneous logit are reported in Table 5.

\footnotetext{
${ }^{16}$ For a more detailed examination of the determinants of the intensity of use of a wide range of intellectual property rights, see Baldwin (1997a).

${ }^{17}$ Some $47 \%$ of large Canadian firms with a major innovation use at least one of the listed forms of intellectual property in Canada, over 30\% do so in the United States, $12 \%$ in Europe and 10\% in the Pacific Rim.
} 
Table 4. Determinants of Product and Process Innovations (Company Weighted)

\begin{tabular}{|c|c|c|c|c|c|c|c|c|c|}
\hline & \multicolumn{3}{|c|}{ Product Only Innovation } & \multicolumn{3}{|c|}{ Product with Process Innovation } & \multicolumn{3}{|c|}{ Process Only Innovation } \\
\hline & Logit & Logit & $\begin{array}{c}\text { Simultaneous } \\
\text { Logit }\end{array}$ & Logit & Logit & $\begin{array}{c}\text { Simultaneous } \\
\text { Logit }\end{array}$ & Logit & Logit & $\begin{array}{c}\text { Simultaneous } \\
\text { Logit }\end{array}$ \\
\hline Intercept & $-5.280 * * *$ & $-5.147 * * *$ & $-5.165 * * *$ & $-4.069 * * *$ & $-3.985 * * *$ & $-4.105 * * *$ & $-3.439 * * *$ & $-3.363 * * *$ & $-3.381 * * *$ \\
\hline $\begin{array}{l}\text { FIRM CHARACTERISTICS } \\
\text { Firm Size } \\
\text { - } 100-499 \text { employees } \\
\text { - } 500 \text { or more employees } \\
\text { Strategies } \\
\text { - technology } \\
\text { - marketing } \\
\text { - production }\end{array}$ & $\begin{array}{l}-0.284 \\
0.712 * * \\
0.455 * * * \\
0.298 * * \\
-0.194\end{array}$ & $\begin{array}{l}-0.185 \\
0.861 * * * \\
0.461 * * * \\
0.353 * * * \\
-0.196\end{array}$ & $\begin{array}{l}0.022 \\
1.501 * * \\
0.605 * * * \\
0.472 * * * \\
-0.283\end{array}$ & $\begin{array}{l}-0.096 \\
0.679 * * * \\
0.436 * * * \\
0.399 * * * \\
-0.180\end{array}$ & $\begin{array}{l}-0.029 \\
0.787 * * * \\
0.456 * * * \\
0.445^{* * *} \\
-0.194\end{array}$ & $\begin{array}{l}0.273 \\
1.816^{* * *} \\
0.574 * * * \\
0.661 * * * \\
-0.285^{* *}\end{array}$ & $\begin{array}{l}-0.121 \\
0.840^{* * *} \\
0.249 * \\
0.284 * * \\
0.057\end{array}$ & $\begin{array}{l}-0.071 \\
0.951 * * * \\
0.297 * * \\
0.325 * * \\
0.046\end{array}$ & $\begin{array}{l}0.044 \\
1.286 * * * \\
0.343 * * \\
0.392 * * \\
0.020\end{array}$ \\
\hline $\begin{array}{l}\text { FIRM ACTIVITIES } \\
\text { R\&D Activity } \\
\text { - R\&D performer } \\
\text { Appropriability } \\
\text { - use of patents } \\
\text { - use of trade secrets } \\
\text { - use of other rights }\end{array}$ & $\begin{array}{l}2.715 * * * \\
0.654 * * \\
0.153 \\
0.980 * * *\end{array}$ & $\begin{array}{c}2.892 * * * \\
0.946 * * * \\
-- \\
---\end{array}$ & $\begin{array}{r}3.382 * * * \\
-1.650 \\
--- \\
---\end{array}$ & $\begin{array}{l}2.184 * * * \\
0.593 * * * \\
0.303 \\
0.591 * * *\end{array}$ & $\begin{array}{c}2.277 * * * \\
0.763 * * * \\
-- \\
---\end{array}$ & $\begin{array}{l}2.933 * * * \\
-2.644 \\
--- \\
---\end{array}$ & $\begin{array}{l}1.293 * * * \\
0.237 \\
0.702 * * \\
0.461 * *\end{array}$ & $\begin{array}{c}1.394 * * * \\
0.516^{* *} \\
-- \\
---\end{array}$ & $\begin{array}{l}1.598 * * * \\
-0.908 \\
--- \\
---\end{array}$ \\
\hline $\begin{array}{l}\text { INDUSTRY CHARACTERISTICS } \\
\text { Competition } \\
\text { - } 6 \text { to } 20 \text { competitors } \\
\text { - over } 20 \text { competitors } \\
\text { Technological Opportunity } \\
\text { - collaborative agreements } \\
\text { Summary statistics: } \\
\mathrm{N} \\
\text { Log Likelihood } \\
\chi^{2}\end{array}$ & $\begin{array}{l}0.503 * \\
-0.299 \\
0.052 * *\end{array}$ & $\begin{array}{l}0.495^{*} \\
-0.349 \\
0.057^{* * * *}\end{array}$ & $\begin{array}{l}0.370 \\
-0.577 \\
0.067 * * *\end{array}$ & $\begin{array}{l}0.577^{* *} \\
-0.043 \\
0.055^{* * * *}\end{array}$ & $\begin{array}{l}0.558^{* *} \\
-0.059 \\
0.060 * * *\end{array}$ & $\begin{array}{l}0.508^{* *} \\
-0.299 \\
0.072 * * *\end{array}$ & $\begin{array}{l}0.765^{* * *} \\
-0.010 \\
0.024\end{array}$ & $\begin{array}{l}0.740 * * * \\
-0.017 \\
0.028\end{array}$ & $\begin{array}{l}0.743^{* * *} \\
-0.101 \\
0.035^{*}\end{array}$ \\
\hline
\end{tabular}

Note: $* * *$ significant at the $1 \%$ level; ** significant at the $5 \%$ level; $*$ significant at the $10 \%$ level. 
Cohen and Klepper (1996a, 1996b) suggest that size should be more closely related to process than product innovation. This, they suggest, is because of the difficulty a firm faces in realizing the return to a process innovation in any way except through own-firm production. Process innovation is too firm-specific to allow for easy transfer of information. In contrast, the fruits of a product innovation are more easily realized by selling it to others. Our results do not directly support this contention. Admittedly, the coefficient on size is significant everywhere in the single equation models and is larger for process-only innovations. However, when the simultaneous model is used, the product/process innovators have the largest coefficient on the largest size class. The effect of size on the probability of innovation is greatest for the combined class (Table 5). This is the most complex form of innovation and may be the type that is best developed by the larger firms.

In previous work that investigates small-firm success, Baldwin and Johnson (1998) find that combined product/process innovators stress a number of complementary strategies more intensely that do either pure product or pure process innovators. The results presented in Table 4 confirm the importance of the complementary strategies in this group. The probability effects of technology and marketing are generally largest and are more significant for the combined product/process group than for the others. None of the groups are more likely to innovate if they give greater stress to production strategies. Thus the substitutability between innovation and the stress that is given to cost reduction is found to exist across all three innovation types.

The emphasis on technology at the firm level is significantly related to innovation in all innovation categories - product innovation, process innovation, and combined product/process innovation. Firms that introduce new product innovations without a change in manufacturing technology still stress the general development of technology. Technological opportunity at the industry level is particularly important for the combined product/process group.

Patents in the single equation models are found to be more closely related to product than process innovation. Our earlier finding that this effect disappears in the simultaneous framework also holds for all three innovation types.

Competition matters more for the two categories that involve process innovation-process-only innovation and combined product/process innovation. In both cases, the non-linearities are the same with competition being greatest for situations where there are between 6 and 20 employees. Firms in this category have about a 10 percentage point higher probability of innovating. Process innovation tends to be associated generally with cost cutting. Product innovation is associated with improvements in quality. Therefore, competition tends to stimulate cost-cutting improvements associated with innovation. It has less of an effect on the quality changes associated with innovation in product markets. 
Table 5. Estimated Probability of Introducing Product and Process Innovations for Simultaneous Logit Model

\begin{tabular}{|c|c|c|c|}
\hline & $\begin{array}{c}\text { Product Only } \\
\text { Innovation }\end{array}$ & $\begin{array}{c}\text { Combined } \\
\text { Product/Process } \\
\text { Innovation }\end{array}$ & $\begin{array}{c}\text { Process Only } \\
\text { Innovation }\end{array}$ \\
\hline \multicolumn{4}{|l|}{$\begin{array}{l}\text { FIRM CHARACTERISTICS } \\
\text { Firm Size }\end{array}$} \\
\hline 1 to 99 employees & 9 & 23 & 15 \\
\hline 100 to 499 employees & 9 & 23 & 15 \\
\hline 500 or more employees & 32 & 65 & 39 \\
\hline \multicolumn{4}{|l|}{ Strategies } \\
\hline Technology & 10 & 26 & 16 \\
\hline + standard deviation & 17 & 39 & 21 \\
\hline - standard deviation & 6 & 17 & 12 \\
\hline Marketing & 10 & 26 & 16 \\
\hline + standard deviation & 15 & 40 & 22 \\
\hline - standard deviation & 7 & 16 & 12 \\
\hline Production & 10 & 26 & 16 \\
\hline + standard deviation & 10 & 21 & 16 \\
\hline - standard deviation & 10 & 32 & 16 \\
\hline \multicolumn{4}{|l|}{ FIRM ACTIVITIES } \\
\hline R\&D Activity & & & \\
\hline R\&D performer & 21 & 40 & 22 \\
\hline Non performer & 1 & 3 & 5 \\
\hline \multicolumn{4}{|l|}{ Appropriability } \\
\hline Patent user & 10 & 26 & 16 \\
\hline Non user & 10 & 26 & 16 \\
\hline \multicolumn{4}{|c|}{ INDUSTRY CHARACTERISTICS } \\
\hline Zero to 5 & 10 & 23 & 13 \\
\hline 6 to 20 & 10 & 33 & 24 \\
\hline Over 20 & 10 & 23 & 13 \\
\hline \multicolumn{4}{|l|}{ Technological Opportunity } \\
\hline Technological opportunity & 10 & 26 & 16 \\
\hline + standard deviation & 14 & 33 & 19 \\
\hline - standard deviation & 8 & 20 & 14 \\
\hline
\end{tabular}




\section{Novelty of Innovation}

\section{Differences Between Innovators and Non-innovators}

Innovations vary in terms of importance. Some are the first of their kind in the world (worldfirsts), some are the first of their kind in Canada (Canada-firsts), while yet others are only new to the firms introducing them (other innovations).

Since the novelty of world-first innovations is greatest, we might expect that the difference between non-innovators and these firms to be different than for other types of innovators. In order to evaluate this hypothesis, we estimate three different logit regressions. In the first case, the dependent variable takes a value of one for a world-first innovation, and zero for noninnovators. The second takes a value of one for a Canada-first innovation, and zero for noninnovators. The third takes a value of one for the other (imitative) innovation category and zero for non-innovators. By comparing the results of the three formulations, we can draw inferences about whether the more novel category-world-firsts - requires different capabilities than the less novel categories - Canada-firsts and 'other' categories. The estimated parameters from the logit regressions are reported in Table 6 . The probability values associated with the simultaneous logit are presented in Table 7.

Size is important in the case of world-firsts and in the other categories - but it has the greatest impact on the probability of introducing 'other' innovations. Scale and scope economies in innovation are not just related to novelty.

It is also the case that $R \& D$ matters for all types of innovations. It also has the greatest impact on the probability of introducing 'other' innovations (Table 7). The importance of R\&D, even in the case of Canada-firsts and 'other' innovators, shows that R\&D is essential to the adaptation of ideas from abroad and from other firms. Not only are R\&D laboratories used to create and develop absolutely novel innovations but they also serve to keep the firm informed about related innovation activity done by other firms and help to adapt it to Canadian conditions.

While competition (at least modest amounts) was important for all innovators taken together (Table 2), the effect of number of competitors disappears for world-firsts in Table 6 in the simple logit. It is significant for the other two categories. This means that changes in the degree of competition are more effective in stimulating firms to imitate others than they are in affecting the introduction of the more novel forms of innovation.

Scientific environment or technological opportunity is important for the creation of all types of innovations. Firms operating in industries that rely more on science-based research are more likely to produce world-firsts, Canada-firsts and other types of innovations. Moreover, the effect on the probability of innovating is about the same in each (Table 7). 
A stress on marketing is also closely associated with all types of innovations but has the greatest impact on the probability of introducing 'other' innovations. In the latter case, marketing is essential if firms are to catch up with leaders. In the former case, the emphasis on marketing confirms the point that adapting to conditions both at home and abroad is important for innovators that are producing brand new products.

Patent use is important for firms producing both world- and Canada-first innovations in the single equation logit model. But it is likely to perform slightly different roles in each case. In the former, patents protect their original inventions. In the latter, foreign innovations are likely to be protected by patents owned by the licensor. And in both cases, this variable is no longer significant when the simultaneous equations model is invoked. 
Table 6. Determinants of World-First and Canada-First Innovations (Company-Weighted)

\begin{tabular}{|c|c|c|c|c|c|c|c|c|c|}
\hline & \multicolumn{3}{|c|}{ World First Innovators } & \multicolumn{3}{|c|}{ Canada First Innovators } & \multicolumn{3}{|c|}{ Other Innovators } \\
\hline & Logit & Logit & $\begin{array}{c}\text { Simultaneous } \\
\text { Logit }\end{array}$ & Logit & Logit & $\begin{array}{c}\text { Simultaneous } \\
\text { Logit }\end{array}$ & Logit & Logit & $\begin{array}{c}\text { Simultaneous } \\
\text { Logit }\end{array}$ \\
\hline Intercept & $-5.912 * * *$ & $-5.819^{* * *}$ & $-5.893 * * *$ & $-3.964 * * *$ & $-3.883^{* * *}$ & $-3.926^{* * *}$ & $-3.378^{* * *}$ & $-3.345^{* * *}$ & $-3.302 * * *$ \\
\hline $\begin{array}{l}\text { FIRM CHARACTERISTICS } \\
\text { Firm Size } \\
\text { - } 100-499 \text { employees } \\
\text { - } 500 \text { or more employees } \\
\text { Strategies } \\
\text { - technology } \\
\text { - marketing } \\
\text { - production }\end{array}$ & $\begin{array}{l}0.113 \\
1.109^{* * *} \\
0.449^{* *} \\
0.390^{* *} \\
-0.501^{* *}\end{array}$ & $\begin{array}{l}0.113 \\
1.205^{* * *} \\
\\
0.514^{* * *} \\
0.398^{* *} \\
-0.504^{* *}\end{array}$ & $\begin{array}{l}0.357 \\
2.023 * * * \\
\\
0.639^{* * *} \\
0.548^{* * *} \\
-0.569^{* *}\end{array}$ & $\begin{array}{l}-0.195 \\
0.340 \\
\\
0.623 * * * \\
0.194 \\
-0.260\end{array}$ & $\begin{array}{l}-0.167 \\
0.440 \\
0.635^{* * *} \\
0.210 \\
-0.253\end{array}$ & $\begin{array}{l}0.237 \\
1.254^{* *} \\
\\
0.786^{* * *} \\
0.348^{* *} \\
-0.244\end{array}$ & $\begin{array}{l}-0.223 \\
0.291 \\
0.270^{* *} \\
0.238^{*} \\
0.093\end{array}$ & $\begin{array}{l}-0.199 \\
0.351 \\
\\
0.270^{* *} \\
0.259^{* *} \\
0.093\end{array}$ & $\begin{array}{l}0.466^{*} \\
1.593^{* * *} \\
0.406^{* * *} \\
0.593^{* * *} \\
0.076\end{array}$ \\
\hline $\begin{array}{l}\text { FIRM ACTIVITIES } \\
\text { R\&D Activity } \\
\text { - R\&D performer } \\
\text { Appropriability } \\
\text { - use of patents } \\
\text { - use of trade secrets } \\
\text { - use of other rights }\end{array}$ & $\begin{array}{l}1.889 * * \\
0.673 * \\
0.501 \\
0.610 *\end{array}$ & $\begin{array}{c}2.015^{* * *} \\
0.951^{* * *} \\
--- \\
---\end{array}$ & $\begin{array}{r}2.439 * * * \\
-1.436 \\
--- \\
---\end{array}$ & $\begin{array}{l}1.550^{* *} \\
0.753^{* * *} \\
0.058 \\
0.546^{* *}\end{array}$ & $\begin{array}{c}1.625^{* * *} \\
0.931^{* * *} \\
--- \\
---\end{array}$ & $\begin{array}{l}2.183 * * * \\
-2.674 \\
--- \\
---\end{array}$ & $\begin{array}{l}1.398 * * * \\
0.051 \\
0.156 \\
0.352\end{array}$ & $\begin{array}{l}1.461^{* * *} \\
0.179 \\
--- \\
---\end{array}$ & $\begin{array}{c}2.298^{* * *} \\
-6.481 * * * \\
--- \\
---\end{array}$ \\
\hline $\begin{array}{l}\text { INDUSTRY CHARACTERISTICS } \\
\text { Competition } \\
\text { - } 6 \text { to } 20 \text { competitors } \\
\text { - over } 20 \text { competitors } \\
\text { Technological Opportunity } \\
\text { - collaborative agreements } \\
\text { Summary statistics: } \\
\mathrm{N} \\
\text { Log Likelihood } \\
\chi^{2}\end{array}$ & $\begin{array}{l}0.212 \\
0.117 \\
0.095^{* * *} \\
\\
899 \\
-175 \\
104.1\end{array}$ & $\begin{array}{l}0.156 \\
0.071 \\
0.103 * * * \\
\\
899 \\
-179 \\
103.3\end{array}$ & $\begin{array}{l}0.107 \\
-0.224 \\
0.112^{* * *} \\
\\
899 \\
-183 \\
85.6\end{array}$ & $\begin{array}{l}0.563^{* *} \\
-0.376 \\
0.029 \\
\\
967 \\
-323 \\
85.8\end{array}$ & $\begin{array}{l}0.544^{*} \\
-0.403 \\
0.030 \\
\\
967 \\
-326 \\
76.6\end{array}$ & $\begin{array}{l}0.351 \\
-0.747 * * \\
0.055^{* *} \\
\\
967 \\
-333 \\
61.5\end{array}$ & $\begin{array}{l}0.654^{* * *} \\
0.158 \\
0.043^{* *} \\
\\
1023 \\
-451 \\
71.3\end{array}$ & $\begin{array}{l}0.642^{* *} \\
0.160 \\
0.045^{* *} \\
\\
1023 \\
-453 \\
67.8\end{array}$ & $\begin{array}{l}0.481 * \\
-0.302 \\
0.055^{* * *} \\
\\
1023 \\
-446 \\
69.3\end{array}$ \\
\hline
\end{tabular}

Note: $* * *$ significant at the $1 \%$ level; $* *$ significant at the $5 \%$ level; $*$ significant at the $10 \%$ level. 
Table 7. Estimated Probability of Introducing World-First, Canada-First and Other Innovations Using the Simultaneous Logit Model

\begin{tabular}{|c|c|c|c|}
\hline & $\begin{array}{l}\text { World-First } \\
\text { Innovators }\end{array}$ & $\begin{array}{c}\text { Canada-First } \\
\text { Innovators }\end{array}$ & Other Innovators \\
\hline \multicolumn{4}{|l|}{$\begin{array}{l}\text { FIRM CHARACTERISTICS } \\
\text { Firm Size }\end{array}$} \\
\hline 1 to 99 employees & 3 & 9 & 13 \\
\hline 100 to 499 emplyees & 3 & 9 & 19 \\
\hline 500 or more employees & 18 & 27 & 42 \\
\hline \multicolumn{4}{|l|}{ Strategies } \\
\hline Technology & 3 & 10 & 16 \\
\hline + standard deviation & 6 & 20 & 22 \\
\hline - standard deviation & 2 & 5 & 11 \\
\hline Marketing & 3 & 10 & 16 \\
\hline + standard deviation & 6 & 14 & 25 \\
\hline - standard deviation & 2 & 7 & 10 \\
\hline Production & 3 & 10 & 16 \\
\hline + standard deviation & 2 & 10 & 16 \\
\hline - standard deviation & 6 & 10 & 16 \\
\hline \multicolumn{4}{|l|}{ FIRM ACTIVITIES } \\
\hline R\&D Activity & & & \\
\hline R\&D performer & 6 & 16 & 24 \\
\hline Non performer & 1 & 2 & 3 \\
\hline \multicolumn{4}{|l|}{ Appropriability } \\
\hline Patent user & 3 & 10 & 0 \\
\hline Non user & 3 & 10 & 30 \\
\hline \multicolumn{4}{|c|}{ INDUSTRY CHARACTERISTICS } \\
\hline Zero to 5 & 3 & 13 & 14 \\
\hline 6 to 20 & 3 & 13 & 20 \\
\hline 20 or more & 3 & 7 & 14 \\
\hline \multicolumn{4}{|l|}{ Technological Opportunity } \\
\hline Technological opportunity & 3 & 10 & 16 \\
\hline + standard deviation & 6 & 13 & 19 \\
\hline - standard deviation & 2 & 8 & 13 \\
\hline
\end{tabular}




\section{Conclusion}

Canada is regarded as having a unique innovation system. It is a small, developed country with an open economy and a substantial amount of foreign investment. These characteristics might be expected to have an effect on its innovation system - a system made up on the one hand of institutions that govern the way in which knowledge is created and disseminated and, on the other hand, of the firms that make up the economy. This paper has focused on the characteristics of firms that are innovators. Several findings are of note:

First, while there is a close connection between innovation and the appropriability climate or patent use, the causal relationship is much stronger going from innovation to the decision to use patents than from the use of patents to innovation. This extends the findings, based on survey evidence (Mansfield, 1986; Levin et al., 1987; Cohen et al., 1996), that patents are not seen by firms to be a very efficacious means of protecting innovations, even though they tend to be used once an innovation occurs.

Second, while developing an R\&D emphasis is important, developing capabilities in a number of different areas is also generally a prerequisite for innovation. In particular, firms that give a stronger emphasis to technological capabilities and to marketing competencies are more likely to be innovators. This is particularly important when it comes to innovations that involve both changes in products and processes, thereby confirming the results of a study that used data on small firms (Baldwin and Johnson, 1998). The emphasis on technology is found for all three types of innovations - world-firsts, Canada-firsts and other. Marketing is found to be positively related to all three types as well.

Third, while technological and marketing capabilities are closely related to the probability that a firm will be an innovator, two other capabilities are not. The emphasis on human resources is not seen to be important - a finding that is contrary to results found for new firms (Baldwin, 2000). The emphasis on strategies that were classified as involving the production process is also not positively related to the probability that a firm is innovative.

Fourth, the two variables that are often used in testing the Schumpeterian hypothesis give mixed results. Size is positively related to innovation, though the relationship is non-monotonic. ${ }^{18}$ Essentially, it is the very largest size class (over 500 employees) that differs significantly from the others in that the largest firms are the most innovative. This relationship is more important for product/process innovations. We find that size matters most for those innovations that are the most complex - those that combine products and processes or those that are world-firsts. This modifies the Cohen and Klepper (1996a, 1996b) hypothesis that size should matter more where information asymmetries make it difficult to realize the fruits from innovative activity by selling the innovation to others. We find this effect largest where both product and process innovations occur.

\footnotetext{
${ }^{18} \mathrm{We}$ also experimented with continuous variables using a quadratic term to capture nonlinearities. Essentially the same results were obtained.
} 
While larger firms are more likely to be innovators, a lack of competition is not positively related to innovation. Indeed, intermediate levels of competition are more closely associated with innovation than the lowest level of competition - though the relationship is non-linear. That is, as we increase the number of competitors, the probability of innovating first increases and then decreases. This effect is particularly evident for innovations involving an aspect of new processes and also for the least novel innovations. Competition matters more in the diffusion process than for the introduction of the most novel world-first innovations.

Fifth, it is noteworthy that foreign-controlled firms are not significantly more likely to innovate generally. This result depends upon the inclusion of the competency and size variables. Thus differences in the raw innovation rates that exist between foreign and domestic firms are accounted for by differences in competencies. ${ }^{19}$

Finally, the scientific regime is a significant determinant of the rate of innovation in total. It also is positively related to product-only, product/process and process-only innovations and it is closely related to both more novel innovations and to those innovations that are just being introduced into Canada for the first time. However, scientific infrastructure also matters in the case of 'other' innovations and the emphasis of 'technological' strategies is important across all three types. This points to the importance of scientific infrastructure across all types of innovation.

${ }^{19}$ That these competencies account for most of the differences between foreign and domestic firms increases our confidence that these variables capture most of the important firm-specific effects in the regression. 


\section{Appendix A}

\section{Data Sources}

Three types of units were sampled: large firms, ${ }^{20}$ small firms, and establishments of large firms located elsewhere than their head office. For large firms, the first four sections of the survey were sent to management in head office, while the last section was sent to plant managers. For small firms, all sections of the questionnaire were sent to the same location.

Consequently, for large firms, the head office responses on general characteristics, R\&D activity, innovation and intellectual property rights, together with the responses of associated plants to the technology questions, provide a comprehensive overview of the firms' innovative and technological capabilities.

Table A1. Parts of the Questionnaire Asked by Sampling Unit

\begin{tabular}{|l|c|c|c|c|c|}
\hline & \multicolumn{5}{|c|}{ Parts of Questionnaire } \\
\cline { 2 - 6 } & General & R\&D & Innovation & $\begin{array}{c}\text { Intellectual } \\
\text { Property }\end{array}$ & Technology \\
\hline Head offices & All & All & All & All & \\
Small firms (group 1) & All & & Some & All & Some \\
Small firms (group 2) & All & All & & & All \\
Large plants & & & & & \\
\hline
\end{tabular}

Small firms were handled somewhat differently. In order to reduce response burden, they were divided into two groups. Each group was asked to answer only part of the questionnaire. One group was asked to answer the R\&D and advanced technology sections, while the other group was asked to answer the innovation and intellectual property sections. Both groups were asked to answer the section on general characteristics. In order to further reduce response burden, small firms were only asked to answer selected questions for certain sections. All of this is summarized in Table A1.

The sample consisted of 1,595 head offices (which answered all but the technology section), 1,954 large plants (which answered only the technology section), and 2,180 small firms - of which 1,088 answered the general, innovation and intellectual property sections, and 1,092 answered the general, $R \& D$, and technology sections. In all, 5,729 units were sampled.

The response rate for the survey was $86 \%$. It ranged from $78 \%$ for large plants to $93 \%$ for one group of the small firms. In this paper, only the responses of large firms are used since only these firms answered the innovation, the intellectual property and the research and development sections together.

20 For the purpose of this survey, large firms are defined as those that are fully profiled in Statistics Canada's Business Register. Typically, they have at least 20 employees, and in many cases, much more than that. Small firms typically have less than 20 employees. 


\section{References}

Abernathy, W.J. and J.M. Utterbach. 1978. "Patterns of Industrial Innovation", Technology Review 80: 41-7.

Acs, Z.J. and D. Audretsch (eds.) 1991. Innovation and Technological Change. Harvester: Wheatsheaf.

Audretsch, D.B. 1995. Innovation and Industry Evolution. The MIT Press.

Äkerblom, M., M. Virtaharju and A. Leppäahti. 1996. "A Comparison of R\&D Surveys, Innovation Surveys and Patent Statistics Based on Finnish Data", Innovation, Patents and Technological Strategies. Paris: OECD.

Arrow, K. 1962. "Economic Welfare and the Allocation of Resources for Invention", in The Rate and Direction of Inventive Activity. Edited by R.R. Nelson. Princeton: Princeton University Press. pp. 609-624.

Arvanitis, S. and H. Hollenstein. 1994. "Demand and Supply Factors in Explaining the Innovative Activity of Swiss Manufacturing Firms", Economics of Innovation and New Technology. 3: 15-30.

Arvanitis, S. and H. Hollenstein. 1996. "Industrial Innovation in Switzerland: A Model-based Analysis with Survey Data", in Determinants of Innovation: The Message from New Indicators. Edited by Alfred Kleinknecht. Amsterdam: Macmillan. pp. 13-62.

Baldwin, J.R. 1997a. Innovation and Intellectual Property. Catalogue No. 88-515-XPE. Ottawa: Statistics Canada.

Baldwin, J.R. 1997b. The Importance of Research and Development for Innovation in Small and Large Canadian Manufacturing Firms. Analytical Studies Branch Research Paper Series No. 107. Ottawa: Statistics Canada.

Baldwin, J.R. 2000. Innovation and Training in New Firms. Analytical Studies Branch Research Paper Series No. 123. Ottawa: Statistics Canada. Forthcoming.

Baldwin, J.R., W. Chandler, Can Le and T. Papailiadis. 1994. Strategies for Success: A Profile of Growing Small and Medium-Sized Enterprises in Canada. Catalogue No. 61-523-RPE. Ottawa: Statistics Canada.

Baldwin, J.R. and M. Da Pont. 1996. Innovation in Canadian Manufacturing Enterprises. Catalogue No. 88-513-XPB. Ottawa: Statistics Canada.

Baldwin, J.R. and P. Gorecki. 1994. "Concentration and Mobility Statistics", Journal of Industrial Economics 42: 93-104. 
Baldwin, J.R. and J. Johnson. 1998. "Innovator Typologies, Competencies, and Performance", in Microfoundations of Economic Growth: A Schumpeterian Perspective. Edited by C. Green and C. McCann. Ann Arbour: University of Michigan Press. pp. 227-253.

Baldwin, J.R. and J. Johnson. 1999. "Entry, Innovation and Firm Growth", in Are Small Firms Important? Their Role and Impact. Edited by Z. Acs. Dordrecht: Kluwer pp. 51-71.

Baldwin, J.R. and J. Johnson. 1995. "Business Strategies in Innovative and Non-Innovative Firms in Canada", Research Policy 25: 785-104.

Baldwin, J.R. and D. Sabourin. 1995. Technology Adoption in Canadian Manufacturing. Catalogue No. 88-512-XPB. Ottawa: Statistics Canada.

Brouwer, E. and A. Kleinknecht. 1996. "Determinants of Innovation. A Microeconometric Analysis of Three Alternative Innovation Output Indicators", in Determinants of Innovation: The Message from New Indicators. Edited by A. Kleinknecht. Amsterdam: Macmillan. pp. 99-124.

Caves, R.E., M.E. Porter, A.M. Spence with J.T. Scott. 1980. Competition in the Open Economy: A Model Applied to Canada. Cambridge: Mass: Harvard University Press.

Caves, R.E. 1982. Multinational Enterprise and Economic Analysis. Cambridge: Cambridge University Press.

Cohen, W. 1996. "Empirical Studies of Innovative Activity", in P. Stoneman (ed.) The Handbook of the Economics of Technological Change. Oxford: Basil Blackwell. pp. 182-264.

Cohen, W. and S. Klepper. 1996a. "A Reprise of Size and R\&D”, Economic Journal 106: $925-$ 952.

Cohen, W. and S. Klepper. 1996b. "Firm Size and the Nature of Innovation Within Industries: The Case of Process and Product R\&D”, Review of Economics and Statistics 78: 232-243.

Cohen, W. and D. Levinthal. 1989. "Innovation and Learning: The Two Faces of R\&D", Economic Journal 99: 569-596.

Cohen, W. and R.C. Levin. 1989. "Empirical Studies of Innovation and Market Structure", in Handbook of Industrial Organization: Vol 2. Edited by R. Schmalensee and R.D. Willig. Elsevier Science Publishers. B.V. pp. 1059-1107.

Cohen, W.M., R.R. Nelson and J. Walsh. 1996. "Appropriability Conditions: Why Firms Patent and Why They Do Not", unpublished paper.

Crépon, B., E. Duguet and I. Kabla. 1996. "Schumpeterian Conjectures: A Moderate Support from Various Innovation Measures", in Determinants of Innovation: The Message from New Indicators. Edited by A. Kleinknecht. Amsterdam: MacMillan. pp. 63-98. 
Crépon, B., E. Duguet and J. Mairesse. 1998. "Research Investment, Innovation, and Productivity: An Econometric Analysis at the Firm Level" \#98.15. Cahiers Eco and Maths. University of Paris 1-Pantheon-Sorbonne.

De Melto, D., K. McMullen and R. Wills. 1980. Innovation and Technological Change in Five Canadian Industries. Discussion Paper No. 176. Ottawa: Economic Council of Canada.

Dunning, J.H. 1993. Multinational Enterprises and the Global Economy. Toronto: AddisonWesley.

Felder, J., G. Licht, E. Nerlinger, and H. Stahl. 1996. "Factors Determining R\&D and Innovation Expenditure in German Manufacturing Industries" in Determinants of Innovation: The Message from New Indicators. Edited by A. Kleinknecht. Amsterdam: MacMillan. pp. 125-54.

Geroski, P., S. Machin and J. Van Reenen. 1993. "The Profitability of Innovating Firms", RAND Journal of Economics 24: 198-211.

Gort, M. and S. Klepper. 1982. "Time Paths in the Diffusion of Product Innovations", Economic Journal 92: 630-53.

Griliches, Z. 1990. "Patent Statistics as Economic Indicators: A Survey”, Journal of Economic Literature. 28: 1661-1707.

Johnson, J., J. Baldwin and C. Hinchley. 1997. Successful Entrants: Creating the Capacity for Survival and Growth. Catalogue No. 61-524-XPE. Ottawa: Statistics Canada.

Kleinknecht, A., T.P. Poot and J.O.N. Reijnen. 1991. "Technical Performance and Firm Size: Survey Results from the Netherlands", in Zoltan J. Acs and David B. Audretsch (eds.) Innovation and Technological Change: An International Comparison. Ann Arbor: University of Michigan Press.

Kleinknecht, A. and B. Verspagen. 1990. "Demand and Innovation: Schmookler Re-examined”, Research Policy 19: 387-394.

Kleinknecht, A.H., J.O.N. Reijnen and W. Smits. 1992. "Collecting Literature-based Innovation Output Indicators. The Experience in the Netherlands", in A.H. Kleinknecht and D. Bain (eds.) 1993. New Concepts in Innovation Output. London: Macmillan.

Klepper, S. 1996. "Entry, Exit, Growth and Innovation over the Product Life Cycle", American Economic Review 86: 562-83.

Klepper, S. and J. H. Millar. 1995. "Entry, Exit and Shakeouts in the Unites States in New Manufactured Products”, International Journal of Industrial Organization 13: 5678-91. 
Kraft, K. 1990. "Are Product- and Process-Innovations Independent of Each Other?" Applied Economics 22: 1029-1038.

Levin, R. and P. Reiss. 1984. "Tests of a Schumpeterian Model of R\&D and Market Structure", in $R \& D$, Patents and Productivity. Edited by Z. Griliches. NBER. Princeton: Princeton University Press. pp. 175-208.

Levin, R.C. and P.C. Reiss. 1988. "Cost-reducing and demand-creating R\&D with spillovers", Rand Journal of Economics 19, pp. 538-556.

Levin, R.C., A.K. Klevorick, R.R. Nelson, and S. G. Winter. 1987. "Appropriating the Returns from Industrial Research and Development”, Brookings Papers on Economic Activity 3: 783-820.

Leo, H. 1996. "Determinants of Product and Process Innovation", Economies et Sociétes, Dynamique technologique et organisation, Série W. Vol. 3: 61-77.

Lunn, J. 1986. "An Empirical Analysis of Process and Product Patenting: A Simultaneous Equation Framework”, The Journal of Industrial Economics 34: 319-330.

Mansfield, E. 1986. "Patents and Innovation: An Empirical Study”, Management Science 32: 173-181.

McFetridge, D. 1993. "The Canadian System of Innovation”, in National Innovation Systems. Edited by R.R. Nelson. Oxford: Oxford University Press. pp. 299-323.

Mowery, D.C. and N. Rosenberg. 1989. Technology and the Pursuit of Economic Growth. Cambridge: Cambridge University Press.

Nelson, R.R. and S.G. Winter. 1982. An Evolutionary Theory of Economic Change. Cambridge Mass.: Harvard University Press.

Pakes, A. and Z. Griliches. 1984. "Patents and R\&D at the Firm Level: A First Look", in $R \& D$, Patents, and Productivity. Edited by Z. Griliches. National Bureau of Economic Research. Chicago: University of Chicago Press.

Robson, M., J. Townsend and K. Pavit. 1988. "Sectoral Patterns of Production and Use of Innovations in the UK: 1945-83", Research Policy 17: 1-14.

Rothwell, R. and W. Zegveld. 1982. Innovation and the Small and Medium-Sized Firm. Frances Pinter: London.

Schankerman, M. 1991. "How valuable is patent protection? Estimates by technology field using patent renewal data.” National Bureau of Economic Research No. 3780. 
Scherer, F.M. 1980. Industrial Market Structure and Economic Performance. Second Edition. Rand McNally: Chicago.

Scherer, F.M. 1983. "The Propensity to Patent", International Journal of Industrial Organization. 1: 107-128.

Scherer, F.M. 1992. "Schumpeter and Plausible Capitalism", Journal of Economic Literature 30: 1416-34.

Schumpeter, J.A. 1942. Capitalism, Socialism, and Democracy. New York: Harper.

Sterlacchini, A. 1994. "Technological Opportunities, Intraindustry Spillovers and Firm R\&D Intensity", Economic Innovation and New Technology 3: 123-37.

Tassey, G. 1991. "The Functions of Technology Infrastructure in a Competitive Economy", Research Policy 20: 345-61. 